\title{
Erratum to: Internal Drivers and Performance Consequences of Small Firm Green Business Strategy: The Moderating Role of External Forces
}

Leonidas C. Leonidou ${ }^{1}$ Paul Christodoulides ${ }^{2}$ - Lida P. Kyrgidou ${ }^{3}$. Dayananda Palihawadana $^{4}$

Published online: 17 June 2015

(C) Springer Science+Business Media Dordrecht 2015

\section{Erratum to: J Bus Ethics}

DOI 10.1007/s10551-015-2670-9

The first name of the corresponding author, the fourth author, in the author group should read Dayananda.

The online version of the original article can be found under doi:10.1007/s10551-015-2670-9.

\footnotetext{
Dayananda Palihawadana

dp@lubs.leeds.ac.uk

University of Cyprus, Nicosia, Cyprus

2 Cyprus University of Technology, Limassol, Cyprus

3 International Hellenic University, Kentriki Makedonia, Greece

4 Leeds University Business School, West Yorkshire, UK
} 